\title{
Research on Small Loan Business of Rural Credit Cooperatives Cooperation in Linjiang City Jilin Province
}

\author{
Yunlei Huo ${ }^{1, \text { a }}$ \\ ${ }^{1}$ Jilin Business and Technology College, Jilin, Jilin, China, 130507 \\ aemail,
}

\begin{abstract}
Keywords: Small Loan Business, Rural Credit Cooperatives Cooperation, Linjiang City, Jilin Province
\end{abstract}

\begin{abstract}
In this paper, we set Linjiang as an example to introduce the basic situation and the problems of Linjiang Rural credit cooperatives cooperation small loan business, and for the development of small loan business market imperfections of Linjiang such as the loan period is unreasonable, low quality of working personnel, lack of professional personnel, less of security, the united retain the risk-sharing mechanism is not perfect and other issues, we put forward appropriate recommendations. And we hope to provide some useful reference for the future development of rural credit cooperatives small loan business of Jilin.
\end{abstract}

\section{The Development Status of Small Loan Business in Rural Credit Cooperatives Cooperation of Linjiang City Jilin Province}

At present, Linjiang rural credit cooperatives cooperation has 18 independent accounting units, 26 business outlets. As to December 31, 2015, the balance of deposits Linjiang city's rural credit cooperative association of 45 billion RMB, the loan balance of 1.6 billion RMB, an increase of $16.8 \%$, up 3 percentage points higher than last year, in which small loans 29.36 million RMB, has achieved total surplus over the entire area, the operating strength has markedly increased. Although since 2010, the rural credit cooperative association of microfinance business Linjiang showing a rising trend, but the overall growth process, the quality of credit assets also declined, credit liquidity risk has also been increased. In 2014, an average of 20 users paid 2,500 RMB, the average turnover rate of $1.49 \%$, the risk of loan ratio reached $25 \%$, in a state of high risk and non-performing loans Linjiang Rural credit cooperatives cooperation microcredit rate of up to $8.43 \%$, much higher than the ratio of bad loans to other commercial banks, has a high risk, therefore, Linjiang RCC should strengthen management, integration of resources, weaknesses, reduce losses and achieve sustainable development.

\section{The Real Problem in Small Loan Business in Rural Credit Cooperatives Cooperation of Linjiang City Jilin Province}

The Development of Small Loan Business Is Still Not Perfect. With the increase of Linjiang microfinance business, they are increasingly exposed to the problems: First, the supply and demand sides of the uneven development of microfinance, household demand is far greater than the maximum amount of credit unions to offer this also gave some small loan companies an opportunity, the opportunity to drive up interest rates or the emergence of the phenomenon of compound interest, some small loan companies and even the annual interest rate has reached 40 percent, which means that to some extent in already affected the development of rural credit cooperatives microfinance business. Second, the rural credit cooperatives cooperation of a micro-lending business is built around the farmers, Rural Credit Cooperatives and the Government are three indispensable systematic engineering, and agriculture as the cornerstone of the national economy, naturally strong state support, often in policy administering certain concessions, which means that government intervention in rural credit cooperatives had to bear a lot of responsibility for policy. For example Linjiang Rural credit cooperatives cooperation in order to meet the needs of farmers, to complete the policy responsibility, sometimes even under this credit union funds are not sufficient conditions, 
use patterns to central bank borrowing, lending loans to farmers, but also to be able to promptly loan, had to ask the farmers in the year of repayment, and some farmers are unable to repay within one year, so this has created a vicious cycle, NPLs. Finally, the micro-lending business Linjiang just related to the currency market, but also not related to the capital markets and the insurance market, the lack of support for a certain amount of money, the larger the risk.

The Term of Small Loan Business Is Unreasonable. Linjiang City, located in the southeast of Jilin Province, temperate monsoon climate, for the local farmers, their income from the basic planting, due to the climate, the local food crops is generally one crop a year, farmers from the borrower to business , harvesting, selling, and then ultimately, revenue, at least have to take a year's time, and duration of microcredit loans are mostly less than one year mainly short term, if the farmer occurred during the loan manpower irresistible the reason for the loan or the longer production cycle of the project, for example, aquaculture, fruit tree planting, then when the farmers will not be able to repay sums due, it is likely to result in deferment, which is that there might be greater use of risk capital, the impact of the implementation of the effect of microcredit. According to the field survey, Linjiang more than $80 \%$ of the farmers will get the loan funds for farming or aquaculture, of which only $30 \%$ are able to guarantee repayment within one year, and the remaining $70 \%$ are uncertainties exist this also explains the $70 \%$ of households could be delayed repayment, even NPLs, with great risk.

Risk-Sharing Mechanism Is Not Perfect. First, microfinance is two sides facing risks from natural and market, farmers' small loans as small loans constitute a major part of the risks they face particularly significant. After all households mainly dependent on the weather, the ability to resist risk is relatively low, when this year there have been unimaginable natural disaster, the loss of its farmers would be immeasurable, nature will not be able to repay.

Secondly, microfinance is facing ante and ex post information asymmetry risk, although in today's modern, information dissemination already fast, but as farmers small loans mainly composed of personnel, due to their own cultural literacy needs to be improved channels and sources of information is relatively small, its ability to access to information is still relatively low, a lot of information is not know until after the event, which also makes the farmers missed a lot of opportunities, income can not be increased, increasing the risk of the market.

Finally, loan management accountability purposes, is not conducive to the promotion of rural credit cooperatives microfinance business, according to the survey Linjiang Rural credit cooperatives cooperation for the purposes of microcredit is a "package release package packet receiving income" credit accountability, since the issuance of the loan proceeds and loan officers are linked to wages, will lead to the mortgage loan officer made conservative phenomenon, and it also led to those who are really in need of loans farmers nowhere to loans, thereby The "hard loans" de phenomenon.

\section{The Development Proposals of Small Loan Business in Rural Credit Cooperatives Cooperation of Linjiang City Jilin Province}

Make Relevant Policies and Regulate the Market Environment. First, Linjiang Rural credit cooperatives cooperation should learn from the outstanding achievements at home and abroad and continue to absorb the lessons of the past, while the relevant departments should also introduce relevant policies as soon as possible, reasonable definition of their legal status, giving it a legal status legal form of funds for rural credit cooperatives, the rights and the obligations to make clear provisions do not only safeguarded the legitimate interests of both lenders and borrowers, but also to ensure that the reform of rural credit cooperatives have good direction, so that the government's management of its rules to be able to promote their better able to develop.

Second, give full play to the role of government, Riverside city hall should be appropriate to provide some preferential policies for rural credit cooperatives and tax cuts.

Again, the government has to deal with small loan companies illegal operation and some malicious users to escape microfinance repayment behavior, increase its administrative penalties, increased costs and the cost of their violations, clean up the market, standardize the market 
environment, to ensure that Pro River City's micro-lending business to develop health.

Finally, establish credibility assurance systems having a high binding, reduce the occurrence of non-performing loans due to the lack of guarantee mechanism caused by the phenomenon. Linjiang for the high rate of non-performing loans, you can create a sound and accurate account information management system, strict management of accounts, for breach of contract and failure to repay the loan or not farmers, give the names announced, and with other financial agency build information sharing mechanism, the future also want to microcredit loans and other financial institutions to take certain measures to restrain farmers, spur farmers to repay on time, thereby reducing the non-performing loan ratio.

Determine the Reasonable Period of Small Loan According to the Actual Situation. Deadline for microfinance unreasonable situation, Linjiang Rural credit cooperatives cooperation should first be based on the actual local situation, to carefully prepare the loan before the survey work; secondly, according to local small and micro enterprises and farmers production and management features, size, growth cycle and risk conditions and other factors, it is reasonable to set the duration of microcredit, for example, a number of small loans for greenhouse cultivation, cultivation of fruit trees, special aquaculture development projects longer repayment period may be appropriately delayed; Lastly, we should break the "loans are not New Year's Eve," saying that the New Year may allow small farmers loans repayment, lenders consider the full reality of demand or because the impact of natural disasters brought about by force majeure, unable to repay paragraph, as the case would be to extend the loan period, the farmers do not meet the production and management of normal funding needs, but also to avoid because of the small and micro businesses or farmers with production and operation period of the loan repayment does not match the added pressure, reducing the time cost loans to farmers to pay.

In addition, Linjiang Rural credit cooperatives cooperation at the time for the majority of farmers should adhere to the "small-based, convenient" principle, breaking the past, "regardless of the production cycle, will be the end of the repayment," the theory of credit granted, more land close to the people, alerted public opinion to respond to popular, better service for our customers.

Improve the Risk Prevention Mechanism and Establish the Agricultural Insurance Compensation Mechanism. First, Linjiang Rural credit cooperatives cooperation should actively learn from the successful experience of foreign countries, and constantly improve the risk prevention mechanism of the credit unions, the establishment of agricultural insurance compensation mechanism. For example, for most farmers face the dual nature of the risk and the market, Linjiang Rural credit cooperatives cooperation should take the initiative to maintain communication and cooperation with the local meteorological department, always abreast of the latest meteorological dynamics of the region, and made the message to the needy farmers reminding farmers as soon as possible to do risk prevention preparation. Secondly, farmers uncertainty of loss, Riverside city government should actively accelerate the establishment of agricultural insurance compensation mechanism, compensation mechanism by agricultural insurance, the loss occurred when the farmers, to give some compensation to make farmers aware of the importance of agricultural insurance, then by means vigorously promote and increase awareness of the insured farmers to make agricultural insurance recognition in the minds of farmers continues to increase, and thus actively participate in, breaking the hearts of the farmers' prosperity arrived, but an accident three years, "the curse. Finally, establish and improve the rural credit system, the individual situation of each farmer entered their respective information management system, the establishment of its electronic archives farmer personal credit rating, the credit rating corresponding to each farmer, and through lectures, radio, Internet and other means of credit information to vigorously promote and publish the results of its assessment, to carry out credit rating activities, accept social supervision, improve the social credit system-wide rural areas, protection of farmers in rural credit cooperatives can be legitimate Microfinance.

\section{References}

[1] Zhang Ruojun. Economic and Technological Cooperation, Vol. 9 (2013) No 53, p.25-26 
[2] Lu Lijun. Jilin Financial Research, Vol. 3 (2014) No 27, p.74-76

[3] Hu XiaoRMB, Liu Binbin, Shi Jinh. Jilin Financial Research, Vol. 6 (2014) No 19, p.144-145 